\title{
Asialoagalacto-Human Chorionic Gonadotropin, a Carbohydrate-modified Variant of Human Chorionic Gonadotropin, Antagonizes the Stimulatory Actions of Bovine Thyroid-stimulating Hormone on Thyroid Function and HLA-DR Expression in Human Thyroid In Vitro and In Vivo
}

\author{
Rudolf Hoermann, Petra-Maria Schumm-Draeger,* Kathrin Rehbach, and Klaus Mann \\ Medical Department II, Klinikum Grosshadern, University of Munich, D-8000 Munich 70; and \\ ${ }^{*}$ Center of Internal Medicine, University of Frankfurt, D-6000 Frankfurt a. M. 70, Federal Republic of Germany
}

\begin{abstract}
The concept of using thyroid-stimulating hormone (TSH) receptor antagonists in the management of Graves' disease is intriguing. Therefore, we investigated a TSH receptor antagonist derived from human chorionic gonadotropin (hCG) with respect to TSH receptor binding, adenylate cyclase activity, thyroid hormone release, and HLA class II antigen expression in vitro and in an in vivo model.

A variant of hCG, asialoagalacto-hCG, like asialo-hCG and unlike hCG itself, inhibited both ${ }^{125}$ I-bTSH binding and cAMP response to bTSH in human thyroid membranes. However, like intact or deglycosylated hCG and unlike asialo-hCG, asialoagalacto-hCG displayed a limited affinity for hepatic asialoglycoprotein receptors, a likely marker for its in vivo turnover rate. It proved capable of inhibiting bTSH-stimulated thyroid hormone release in human thyroid slices as well as in the nude mouse bearing human thyroid transplants. It also prevented bTSH induced hypertrophy of transplanted thyrocytes. Further, HLA-DR expression induced by bTSH in the presence of $\gamma$-interferon on human thyrocytes was inhibited.

In conclusion, we present evidence that asialoagalacto-hCG antagonizes bTSH actions on thyroid function and HLA-DR expression in human thyroid in vitro and, more importantly, in an in vivo model. Hence, the hCG variant described here or similar agents should warrant further exploration in the study and treatment of Graves' disease. (J. Clin. Invest. 1991. 88:1947-1954.) Key words: hCG variant $\bullet$ TSH receptor $\bullet T_{3}$ release $\bullet D R$ antigen $\cdot$ nude mouse
\end{abstract}

\section{Introduction}

Binding of thyroid-stimulating hormone $(\mathrm{TSH})^{1}$ to its receptor in the thyroid gland initiates a series of events that finally result

A portion of these findings has been presented in abstract form at the 34th and 35th Meeting of the German Endocrine Society (1990. Acta Endocrinol. Suppl. 122:35, and 1991. Acta Endocrinol. Suppl. 124:15).

Address reprint requests to Dr. Rudolf Hoermann, M.D., Medical Department II, Klinikum Grosshadern, University of Munich, Marchioninistr. 15, D-8000 Munich 70, Germany.

Received for publication 18 December 1990 and in revised form 12 July 1991

1. Abbreviations used in this paper: bTSH, bovine thyroid-stimulating hormone; hCG, human chorionic gonadotropin; HF, hydrogenfluoride; $\mathrm{T}_{3}$, triiodothyronine; $\mathrm{T}_{4}$, thyroxine; $\mathrm{TSH}$, thyroid-stimulating hormone.

J. Clin. Invest.

(c) The American Society for Clinical Investigation, Inc.

0021-9738/91/12/1947/08 \$2.00

Volume 88, December 1991, 1947-1954 in an enhancement of the synthesis and secretion of thyroid hormones. Basically, the same mechanisms are operative also under pathological conditions in patients with Graves' disease, because thyroid-stimulating immunoglobulins bind to the TSH receptor, mimic the actions of TSH and induce an uncontrolled hyperstimulation of the thyroid gland (1). In addition to their role in maintaining thyroid hyperfunction, Graves' immunoglobulins are also believed to propagate the underlying immunological disorder by enhancing thyroid antigen presentation, particularly aberrant expression of HLA class II antigens on the surface of thyrocytes (2). In this respect, TSH is also capable of increasing $\gamma$-interferon induced HLA-DR expression by thyrocytes suggesting that this effect may be mediated via TSH receptor (3). Hence, TSH receptor antagonists would theoretically offer an ideal approach to treating Graves' disease. In fact, over the past decades several compounds have been described that are capable of inhibiting the binding of labeled TSH to its receptor and of blocking TSH-stimulated adenylate cyclase activity, among them mainly deglycosylated forms of TSH, synthetic peptides representing parts of the alpha- or beta-subunit of TSH, and variants of human chorionic gonadotropin (hCG) (4-9). For some of these agents an efficacy of blocking the response to Graves' immunoglobulins has been investigated, too $(10,11)$.

However, in this respect an in vivo bioactivity of these agents has never been shown and is unlikely to exist considering their limited persistence in the circulation. In the present studies, we have therefore attempted to obtain by chemical modification of the hCG molecule a TSH receptor antagonist that would combine the properties of a strong thyroid inhibitory activity and a sufficient plasma survival rate to retain some bioactivity in vivo. For this purpose, we investigated the effects of carbohydrate modified hCG variants on human thyroid in vitro with respect to TSH receptor binding, formation of the second messenger CAMP, and hormonal endpoint response, i.e., $T_{3}$ release. In addition, we studied their ability to inhibit the binding of ${ }^{125} \mathrm{I}$-asialo-hCG to liver membranes, a likely marker for their in vivo turnover rate. By these means we succeeded in identifying variant forms of hCG, asialoagalactohCG, and deglycosylated hCG, that seemed to offer some potential to block thyroid stimulation in vivo. AsialoagalactohCG was then tested in the nude mouse model to determine its biological activity under in vivo conditions. Thereby, we assessed its capability to inhibit both stimulation of thyroid hormone production by bTSH and expression of HLA-DR antigen on human thyrocytes induced by bTSH and $\gamma$-interferon.

\section{Methods}

Hormones. Crude hCG $(\sim 2,500 \mathrm{IU} / \mathrm{mg})$ was obtained from Ayerst Laboratories (Rouses Point, NY), hCG CR 123 (12,800 IU/mg), and 
its purified $\beta$-subunit from the Center of Population Research, National Institute of Child Health and Human Development. Highly purified bTSH for radioiodination ( $\sim 30 \mathrm{IU} / \mathrm{mg}$ ) was a generous gift of Dr. J. G. Pierce, University of California (Los Angeles, CA), unlabeled bTSH (Thytropar, $10 \mathrm{IU} / \mathrm{mg}$ ) for in vitro studies was purchased from Armour Pharmaceutical Co. (Chicago, IL) and $\mathrm{T}_{3}$ for RIA standard from Henning (Berlin, Germany). For in vivo studies bTSH (Thyreostimulin, $\sim 0.5 \mathrm{IU} / \mathrm{mg}$ ) from Organon (Oberschleissheim, Germany) was used.

Enzymes and reagents. Immobilized neuraminidase from Clostridium perfringens, type VI-A, $\beta$-galactosidase from Aspergillus niger, grade $\mathrm{V}$, and orosomucoid were obtained from Sigma Chemical Co. (Deisenhofen, Germany), human recombinant $\gamma$-interferon $\left(2 \times 10^{7}\right.$ $\mathrm{IU} / \mathrm{mg}$ ) from Boehringer Mannheim GmbH (Mannheim, Germany). Polyclonal sheep anti- $\mathrm{T}_{3}$-antibody was a generous gift of Henning (Berlin, Germany), polyclonal goat anti- $\mathrm{T}_{4}$-antibody was purchased from Bio-Yeda, Kiryat Weizmann (Rehovot, Israel), monoclonal antibody HLA-DR-IOT 2a from Dianova-Immunotech (Marseilles, France) rabbit anti-goat IgG from Renner (Dannstadt, Germany) and rabbitanti-mouse IgG, IgA, IgM alkaline phosphatase coupled $F\left(a^{\prime}\right)$ fragment from Zymed (San Diego, CA). Ultrafiltration membranes were obtained from Diaflo Amicon Corp. (Danvers, Ireland). ${ }^{125}$ Iodide, ${ }^{131}$ iodide, and the cAMP RIA kits were purchased from AmershamBuchler (Braunschweig, Germany).

Preparation of $h C G$ and its variant forms. Purified hCG (hCG) was isolated from crude hCG by sequential chromatography on columns of DEAE-52 and Sephadex G-100 and was indistinguishable from hCG CR 123 (NIH) in its immunological and biological properties, as has been described in detail previously (9). To obtain asialo-hCG, hCG was desialylated according to the method of van Hall et al. (12) following a protocol we had previously employed $(9,13): 10 \mathrm{mg}$ of hCG were incubated in $0.1 \mathrm{M} \mathrm{Na}$-acetate buffer, $\mathrm{pH} 5.6$, at $37^{\circ} \mathrm{C}$ for $30 \mathrm{~min}$, together with $0.2 \mathrm{IU}$ of immobilized neuraminidase from Clostridium perfringens. The sialic acid content was determined before and after neuraminidase digestion by the colorimetric method of Warren after acid hydrolysis $\left(0.1 \mathrm{~N} \mathrm{H}_{2} \mathrm{SO}_{4}, 80^{\circ} \mathrm{C}, 1 \mathrm{~h}\right)(14)$. The removal of $>80 \%$ of the original sialic acid was documented.

Asialoagalacto-hCG was then prepared by further enzymatic digestion of asialo-hCG with $\beta$-galactosidase from Aspergillus niger. Initially, asialo-hCG $(5 \mathrm{mg})$ was treated with the enzyme $(1 \mathrm{IU} / \mathrm{ml}$, prewashed with incubation buffer) in $0.05 \mathrm{M} \mathrm{Na-acetate} \mathrm{buffer,} \mathrm{pH} 4.6$, at $37^{\circ} \mathrm{C}$ for $1-48 \mathrm{~h}$, following the method of Bahl (15) (procedure 1). Later, this procedure was modified to digestion at room temperature (procedure 2). The reaction was stopped by removing the enzyme with the use of an ultrafiltration chamber (Amicon Corp., Danvers, MA) (membrane YM 100, cut-off 100,000 mol wt). The material was then concentrated by ultrafiltration with a PM 10 membrane (cut-off 10,000 mol wt) and lyophilized. Galactose concentrations released during $\beta$ galactosidase digestion were measured by the copper reduction method of Somogyi and Nelson $(15,16)$. During an incubation of $24 \mathrm{~h} \sim 80 \%$ of the original galactose residues were removed. For all biological studies material that has been digested at $20^{\circ} \mathrm{C}$ for $24 \mathrm{~h}$ was used. Deglycosylated hCG was prepared according to the hydrogen fluoride-method of Keutmann and co-workers (17), as described in detail in a recent paper of ours (18). This method removes $\sim 60-80 \%$ of total carbohydrate with substantial amounts of $N$-acetylglucosamin and $N$-acetylgalactosamine still remaining attached.

Isoelectric focusing (IEF) and immunoblotting. IEF was performed on polyacrylamide gels as described in detail elsewhere (19) (T: 7.7\%, C: $\left.3 \%, \mathrm{pH} 3-10,15 \mathrm{~W}, 10^{\circ} \mathrm{C}, 90 \mathrm{~min}\right)$. After electrofocusing, proteins were transferred to nitrocellulose sheets according to the method of Kyhse-Anderson (20) using a semidry graphite blotter. Immunoblotting of hCG activity was performed by incubation with a specific monoclonal antibody (3/6) against hCG- $\beta$. Bands were visualized by an alkaline phosphatase coupled antibody (rabbit-anti mouse IgG, IgA, IgM $\mathrm{F}\left(\mathrm{ab}^{\prime}\right)$ fragment) and 5-bromo-4-chloro-3-indolyl phosphate/nitroblue tetrazolium staining.

Immunoradiometric assays for $h C G$ and its free beta-subunit. The immunological activities of hCG preparations were assessed by im- munoradiometric assays (IRMAs), specific for holo-hCG and free betasubunit of hCG, respectively. Monoclonal antibodies employed, i.e., 11/6 (against holo-hCG and LH), 3/6 (hCG and $\beta$-subunit), 12/17 (hCG and $\beta$-subunit), and $2 / 6$ (specific for the $\beta$-subunit of hCG), were raised and purified by Dr. K. Siddle, University of Cambridge, UK, as reported previously (21). Assay procedures and assay characteristics have been described in detail in previous reports from our laboratory $(22,23)$. The assay, which employs the monoclonal antibodies, $3 / 6$ as solid phase antibody and $11 / 6$ as tracer, measures holo-hCG with negligible cross-reactivity with free beta-subunit of hCG $(<0.01 \%)$. The second assay, using $2 / 6$ as solid phase antibody and $12 / 17$ as tracer, is specific for the free beta-subunit of hCG its cross-reactivity with holohCG being only $0.4 \%(23)$.

Radioiodination of hormones and antibodies. A stoichiometric chloramine-T technique was used for ${ }^{125} \mathrm{I}$-labeling of highly purified bTSH, hCG, mAb 12/17 and mAb 11/6 (24). ${ }^{125}$ I-asialo-hCG was obtained by neuraminidase treatment of ${ }^{125} \mathrm{I}-\mathrm{hCG}$, similar to the procedure for preparing the unlabeled hormone described above. The substances had specific activities in the range of 30 to $50 \mu \mathrm{Ci} / \mu \mathrm{g}$ and retained their biological activities, as described previously.

Binding studies to human testis membranes. A $10,000 \mathrm{~g}$ particulate fraction was prepared from surrounding normal human testicular tissue collected at surgery from patients with testicular cancer. Binding of ${ }^{125} \mathrm{I}-\mathrm{hCG}\left(3 \times 10^{-11} \mathrm{M}\right)$ to testis membranes $(30 \mu \mathrm{g}$ protein $/ 0.3 \mathrm{ml}$ reaction mixture) was studied in the presence and absence of various inhibitors in $20 \mathrm{mM}$ Tris-Cl buffer, $\mathrm{pH} 7.45$, containing $0.1 \%$ BSA for $18 \mathrm{~h}$ at room temperature. Nonspecific binding was determined by adding $600 \mathrm{mU} / \mathrm{ml}$ crude hCG (9).

Binding studies to human thyroid membranes. Human thyroid tissue obtained at surgery from patients with endemic goiter was processed to a $10,000 \mathrm{~g}$ particulate fraction, as described in detail previously $(9,13)$. Binding of ${ }^{125} \mathrm{I}-\mathrm{bTSH}\left(3 \times 10^{-11} \mathrm{M}\right)$ to the thyroid membrane fraction $(30-50 \mu \mathrm{g}$ protein per $0.3 \mathrm{ml})$ was studied in $50 \mathrm{mM}$ Tris-acetate- $0.1 \%$ BSA buffer, $\mathrm{pH} 7.45$, for $18 \mathrm{~h}$ at $22^{\circ} \mathrm{C}$, conditions which have been reported to expose the high affinity sites of the TSH receptor $(9,25)$. Nonspecific binding was measured in the presence of excess unlabeled bTSH $(1.66 \mathrm{IU} / \mathrm{ml})$

Binding studies to rat liver membranes. To study the influence of various inhibitors on the binding of ${ }^{125} \mathrm{I}$-asialo-hCG $\left(3 \times 10^{-11} \mathrm{M}\right)$ a membrane fraction was prepared from rat liver, as described in detail previously (13). Incubation was carried out in $20 \mathrm{mM}$ Tris-Cl-0.1\% BSA buffer, $\mathrm{pH} 7.45$, containing $0.4 \mathrm{mM} \mathrm{CaCl}_{2}$, for $1 \mathrm{~h}$ at $37^{\circ} \mathrm{C}$ with $30-50 \mu \mathrm{g}$ protein per $0.3 \mathrm{ml}$ reaction mixture. Nonspecific binding was determined in the presence of excess unlabeled asialo-orosomucoid ( $500 \mu \mathrm{g} / \mathrm{ml}$, obtained by desialylation of orosomucoid).

Adenylate cyclase activity in human thyroid membranes. Following a procedure of Orgiazzi et al. (26), human thyroid tissue was immediately processed to a particulate fraction, as described previously (9). $30-40 \mu \mathrm{g}$ of membrane protein was incubated at $37^{\circ} \mathrm{C}$ for $30 \mathrm{~min}$, together with various substances, in $250 \mu$ of reaction mixture $(20 \mathrm{mM}$ Tris-Cl, $3 \mathrm{mM}$ Tris-ATP, $0.05 \mathrm{mM}$ inosine triphosphate, $6 \mathrm{mM} \mathrm{MgCl}$, $0.1 \mathrm{mM}$ isobuthylmethylxanthine, $10 \mathrm{mM}$ phosphocreatine, $0.3 \mathrm{mg} /$ $\mathrm{ml}$ rabbit creatine kinase, $0.1 \% \mathrm{BSA}, \mathrm{pH} 7.7$ ). cAMP concentrations were measured in the supernatant with the use of a commercial RIA-kit.

Studies of $T_{3}$ release from human thyroid slices. $T_{3}$ release from human thyroid slices was studied using a bioassay modified according to Atkinson and Kendall-Taylor (27), as described in detail previously (19). Thyroid slices $(1 \times 1 \times 0.5 \mathrm{~mm})$ were incubated with the various inhibitors in a two chamber dialysis system in modified Earles' buffer containing in addition $2 \mathrm{~g} /$ liter gelatine, $2 \mathrm{~g} /$ liter glucose, $100 \mathrm{IU} /$ liter insulin and antibiotics (penicilline and streptomycine) under $95 \% \mathrm{O}_{2}$ $5 \% \mathrm{CO}_{2}$ atmosphere, for $5 \mathrm{~h}$ at $37^{\circ} \mathrm{C}$. Quadruplicate determinations were performed for each point. $\mathrm{T}_{3}$ released into the medium was measured by a sensitive RIA after equilibrium dialysis for free hormones.

In vivo studies of thyroid hormone production and HLA-DR expression in the nude mouse. Normal human thyroid tissue obtained at surgery (neck dissection) from patients with head and neck cancer was transplanted to athymic nude mice (strain NMRI, age 5-6 wk, weight 
28-30 g), with each animal receiving two transplants of a size of $\sim 4$ $\times 3 \times 2 \mathrm{~mm} .8 \mathrm{wk}$ after transplantation, mice were injected intravenously on two consecutive days with saline $(0.1 \mathrm{ml}), \mathrm{bTSH}(0.1 \mathrm{mIU} /$ animal) or various doses of asialoagalacto-hCG $(0.25,0.5,1 \mathrm{mg} / \mathrm{ani}-$ mal) alone or followed by $0.1 \mathrm{mIU}$ of bTSH 5 min later. In another series of animals, bTSH dose was increased to $100 \mathrm{mIU}$ per animal to find out if a higher TSH dose may overcome the thyroid blockade by asialoagalacto-hCG indicating a competitive mode of action of the inhibitor. On the second day of the experiment, $5 \mu \mathrm{Ci}$ of ${ }^{131}$ iodide were given i.v. to label thyroid hormones that were newly synthesized. Thyroxine production was then estimated by measuring ${ }^{131} \mathrm{I}$-thyroxine in the serum of the animals $24 \mathrm{~h}$ after ${ }^{131} \mathrm{I}$ administration with the use of a double antibody technique (goat anti- $\mathrm{T}_{4}$-antibody and rabbit anti-goat IgG). Results were related to ${ }^{131} I$ content in the serum sample and expressed as a percentage of ${ }^{131} \mathrm{I}$-thyroxine to total radioactivity. At the end of the experiment, thyroid transplants were removed, stored frozen $\left(-70^{\circ} \mathrm{C}\right)$, and used for histological and histomorphological examinations. Particularly, nuclear volume of thyrocytes was assessed, because this is known to be a sensitive marker of functional stimulation of endocrine glands. This experimental nude mouse model briefly described above has been well standardized and widely employed by our group for studies related to a variety of aspects of the physiology of human thyroid under in vivo conditions, including stimulation of cellular hypertrophy and hormone production by bTSH and other thyroid stimulators $(28,29)$.

To study HLA-DR expression by normal human thyroid transplants we followed a recently employed protocol (30). Briefly, $\gamma$-interferon (200 IU/day) was continuously administered via an i.p. minipump (Alzet model 2002, Alzet, London, UK) for $3 \mathrm{~d}$ and bTSH injected in single doses of $0.1 \mathrm{mIU} / \mathrm{animal}$ on each day. To assess its influence on $\mathrm{bTSH} / \gamma$-interferon induced DR expression, asialoagalacto-hCG was tested in doses of $0.25,0.5$, and $1 \mathrm{mg}$ per animal, administered i.v. 5 min before bTSH. Control experiments included saline, bTSH alone, asialoagalacto-hCG alone, $\gamma$-interferon alone, and a combination of $\gamma$-interferon and asialoagalacto-hCG. DR expression was visualized by staining of frozen thyroid transplant sections with MAb. Percentage of DR-positive cells was determined by examination of five sections (magnification, $10 \times 16$ ) from different areas of each transplant comprising at least 100 follicular cells each.

In addition, in some experiments we have measured concentrations of holo-hCG immunoreactivity present in the serum of the mice 20 min after injecting asialoagalacto-hCG. The protocol of the present studies was approved by the local ethic committee and performed in compliance with the guidelines for animal research contained in the declaration of Helsinki.

Measurement of protein concentrations. Protein concentrations of membrane preparations were estimated by the method of Bradford (31), with BSA as a standard.

Statistical methods. For statistical analysis of data Wilcoxon's test for unpaired observations was used.

\section{Results}

Evaluation of optimum conditions for preparation of asialoagalacto-hCG and characterization of $h C G$ variants. When asialohCG was treated with $\beta$-galactosidase according to procedure 1 , the majority of the material dissociated into its free subunits as evidenced by a reduced immunological activity in the holohCG specific IRMA (data not shown) and a corresponding increased reactivity in the IRMA specific for the free betasubunit of hCG (Fig. $1 \mathrm{~A}$ ). In contrast, galactose digestion at room temperature (procedure 2) over the same period of time released only a proportion of $<4 \%$ of free beta subunit (Fig. 1 $B$ ). Therefore, asialoagalacto-hCG obtained by $24 \mathrm{~h}$ digestion at $20^{\circ} \mathrm{C}$ was used for further studies.

hCG, asialo-hCG, asialoagalacto-hCG, and deglycosylated

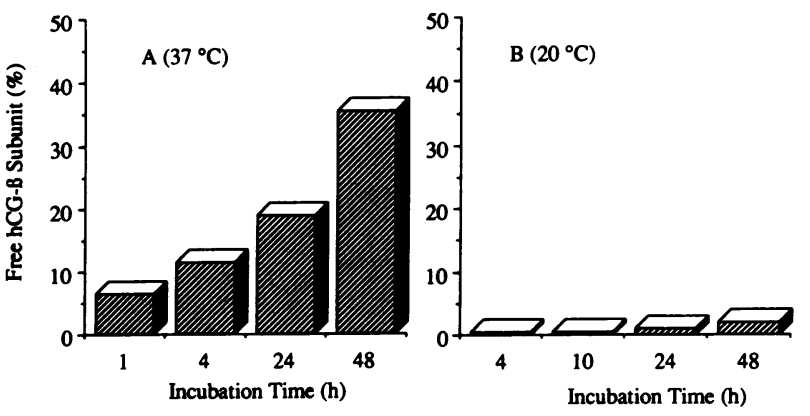

Figure 1. Release of free hCG- $\beta$ subunit during incubation of asialohCG with $\beta$-galactosidase from Aspergillus niger at $20^{\circ} \mathrm{C}$ and $37^{\circ} \mathrm{C}$.

Free beta-subunit was determined by a specific IRMA with negligible cross-reactivity with intact hCG and was expressed as percentage of weight of the material.

hCG showed comparable immunoreactivities and parallel dose response curves in specific holo-hCG IRMA (data not shown). In the hCG radioreceptor assay using human testis membranes, when compared on a weight basis with the standard hCG at half-maximum inhibitory concentrations, deglycosylated hCG was the most active substance showing $300 \%$ of the hCG activity. Asialo- and asialoagalacto-hCG were next in potency ( $\sim 200 \%$ of the hCG activity, data not shown). When subjected to isoelectric focusing and immunoblotting, hCG showed several bands in a pI range of 4-6.8. In contrast, the modified hCG forms asialo-hCG, asialoagalacto-hCG, and deglycosylated hCG focused close to the cathode (Fig. 2).

Binding of $h C G$ forms to thyroid and liver membranes. The affinities of hCG forms for thyroid TSH-receptors and for hepatic asialoglycoprotein receptors were estimated by their abilities to inhibit the binding of ${ }^{125} \mathrm{I}-\mathrm{bTSH}$ to human thyroid membranes and that of ${ }^{125} \mathrm{I}$-asialo-hCG to rat liver membranes, respectively. hCG showed very little affinity for both thyroid and hepatic receptors and removal of sialic acid (asialo-hCG) resulted in a sharp enhancement of the binding to both receptor types.

When further carbohydrates, particularly terminal galactose residues, were removed, opposite effects on the interaction

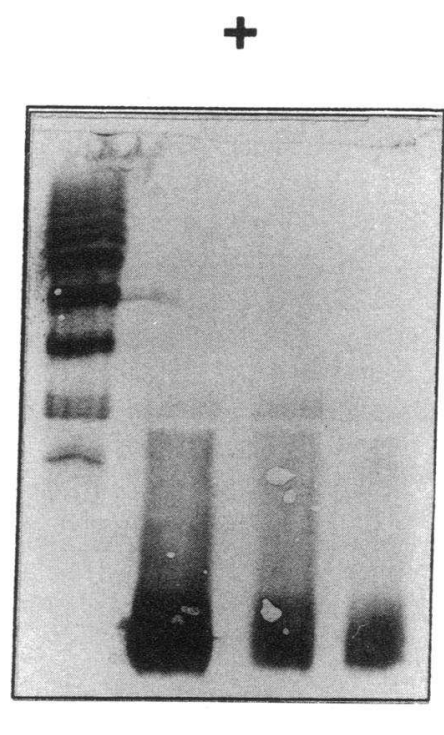

Figure 2. Isoelectric focusing of hCG and its variants. After IEF, hCG immunoreactivity was visualized by immunoblotting with a MAb against the $\beta$-subunit of hCG. hCG is shown in lane 1 , asialo-hCG in lane 2 , asialoagalacto-hCG in lane 3 , and deglycosylated $\mathrm{hCG}$ in lane 4. 


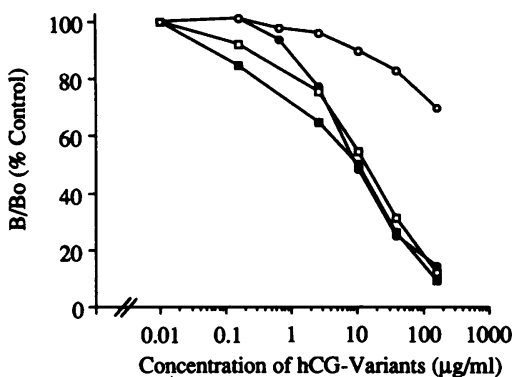

Figure 3. Inhibition of the binding of ${ }^{125} \mathrm{I}$ bTSH to human thyroid membranes by hCG variants: hCG (0), asialo-hCG (๑), asialoagalacto-hCG (口), deglycosylated hCG (ם). Studies of ${ }^{125}$ I-bTSH binding shown here were conducted in 50 $\mathrm{mM}$ Tris-acetate- $0.1 \%$

BSA, pH 7.45, at $22^{\circ} \mathrm{C}$ for $18 \mathrm{~h}$. Results were expressed as a percentage of specific binding compared to the control value obtained in the absence of inhibitor. Each point represents the mean of closely concuring duplicate determinations. Specific binding of ${ }^{125} \mathrm{I}-\mathrm{bTSH}$ was $11 \%$ in this experiment.

with the two receptors were observed. At the thyroid receptor, the activity of asialoagalacto-hCG to inhibit the binding of ${ }^{125} \mathrm{I}$ bTSH was slightly increased compared to asialo-hCG, whereas the affinity of the substance for the hepatic asialoglycoprotein receptors was greatly diminished. Removal of most of the remaining carbohydrate moieties of hCG (deglycosylation) was then associated with a slight increase in TSH binding inhibiting activity, but did not significantly affect binding to liver membranes (Figs. 3,4). To determine specificity of the interaction of desialylated hCG variants with TSH receptor, another glycoprotein, orosomucoid, was desialylated and tested together with the various forms of hCG. Asialo-orosomucoid, as expected, was a potent inhibitor of ${ }^{125} \mathrm{I}$-asialo-hCG binding to liver membranes, but did not significantly affect ${ }^{125} \mathrm{I}-\mathrm{bTSH}$ binding to thyroid membranes (data not shown).

Inhibition of bTSH-stimulated adenylate cyclase activity and $T_{3}$ release by hCG variants in human thyroid in vitro. Whereas hCG itself failed to inhibit bTSH stimulation of adenylate cyclase activity in human thyroid membranes, asialohCG, asialoagalacto-hCG, and deglycosylated hCG revealed a concentration-dependent inhibitory effect in this respect. Compared on a weight basis, deglycosylated hCG was the most potent inhibitor of bTSH action, closely followed by asialoagalacto-hCG, and asialo-hCG was the least potent of these inhibitors (Fig. 5). All substances were unable to stimulate adenylate cyclase activity when tested by themselves in the absence of bTSH (data not shown).

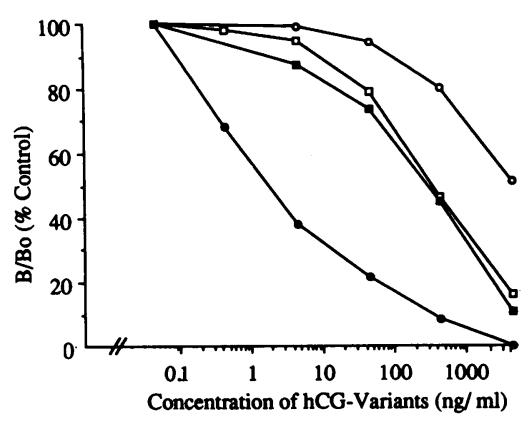

Figure 4. Inhibition of the binding of ${ }^{125} \mathrm{I}$ asialo-hCG to rat liver membranes by various forms of hCG: hCG (o), asialo-hCG (•), asialoagalacto-hCG (口), deglycosylated hCG (a). Duplicate determinations were made for each point. Binding experiments were conducted in $20 \mathrm{mM}$ Tris- $\mathrm{HCl}-0.4$

$\mathrm{mM} \mathrm{CaCl}{ }_{2}-0.1 \% \mathrm{BSA}, \mathrm{pH} 7.45$ at $37^{\circ} \mathrm{C}$ for $1 \mathrm{~h}$. Results shown are the mean of duplicate determinations in a single assay. Specific binding of ${ }^{125} \mathrm{I}$-asialo-hCG was $15 \%$.

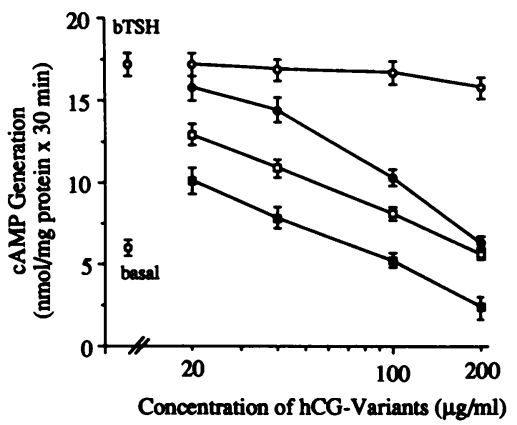

Figure 5. Inhibition of adenylate cyclase response to bTSH $(0.2$ $\mathrm{mIU} / \mathrm{ml}$ ) in human thyroid membranes by various forms of hCG: hCG (o), asialo-hCG $(\bullet)$, asialoagalacto-hCG (), deglycosylated hCG (ロ). Results shown are the means of triplicate determinations $(x \pm \mathrm{SD})$.

Two of the inhibitors, asialo-hCG and asialoagalacto-hCG, were also tested for their influence on hormone response to bTSH. They showed a dose-dependent inhibition of bTSH stimulated $\mathrm{T}_{3}$ release in human thyroid slices, as depicted in Fig. 6.

In vivo studies of thyroid hormone production in the nude mouse. In the nude mouse, bTSH induced a dose-dependent stimulation of thyroxine production as measured by an increase in ${ }^{131} \mathrm{I}$-thyroxine in the serum $24 \mathrm{~h}$ after administration of radioactive iodide. This was true for animals with and without human thyroid transplants. However, the magnitude of stimulation was considerably higher in animals bearing transplants. In the absence of transplants basal production of ${ }^{131} \mathrm{I}$ thyroxine was $10.9 \pm 2.4 \%($ mean $\pm \mathrm{SD}, n=3)$, and stimulation by $0.1 \mathrm{mIU}$ bTSH on two consecutive days, as described under Methods, resulted in an increase to $25 \pm 5 \%(n=3, P<0.01)$. After injections of $0.1 \mathrm{mIU} /$ animal bTSH to animals bearing human thyroid transplants ${ }^{131}$ I-thyroxine amounted to $33.3 \pm 2.2 \%(n=6)$ of total radioactivity in the serum sample, compared to $13.6 \pm 0.96 \%$ in the absence of the hormone ( $n$ $=3, P<0.01$ ). Asialoagalacto-hCG when given intravenously before bTSH injections to nude mice bearing transplants was able to reduce the bTSH related rise in serum concentrations of ${ }^{131}$ I-thyroxine in a dose dependent manner, as is shown in Fig. 7. At the highest dose of asialoagalacto-hCG tested $(1 \mathrm{mg} / \mathrm{ani}-$ mal) bTSH response was nearly completely abolished (Fig. 7). In contrast, basal production of ${ }^{131}$ I-thyroxine was not significantly affected by comparable doses of asialoagalacto-hCG

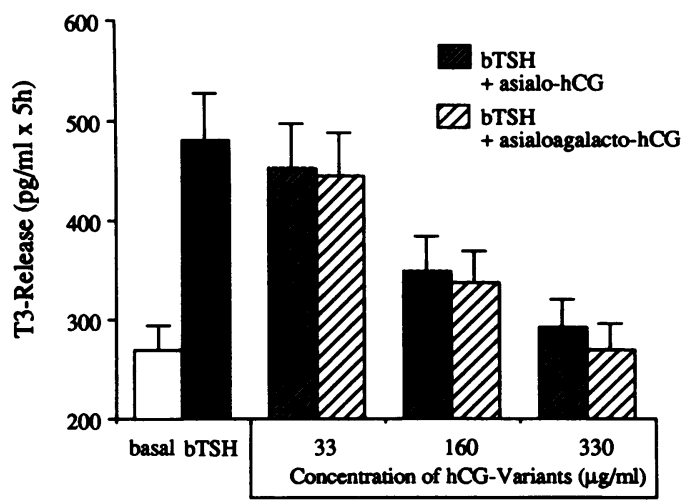

Figure 6. Effect of asialo-hCG and asialoagalacto-hCG on $\mathrm{T}_{3}$ release in human thyroid slices. Each value represents the mean of quadruplicate determinations $(x \pm \mathrm{SD})$. The data show a dose related inhibition of $\mathrm{T}_{3}$ release induced by $10 \mathrm{mIU} / \mathrm{ml} \mathrm{bTSH}$ by both $\mathrm{hCG}$ variants. 


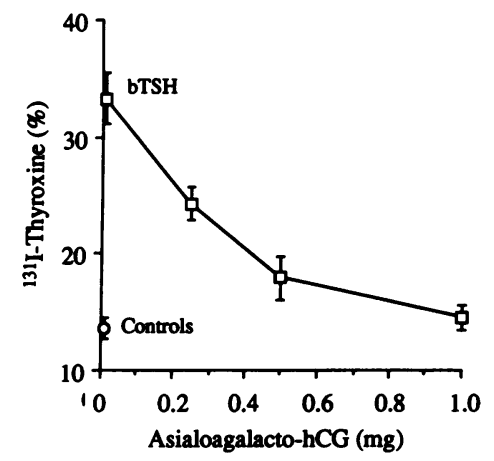
Thyroxine released into the serum was radioactively labeled, and expressed as percentage of ${ }^{131}$ I-thyroxine to total radioactivity in the serum sample, as described under Methods. Results in the bTSH and bTSH plus $1 \mathrm{mg}$ asialoagalacto-hCG group were obtained in six animals (mean $\pm \mathrm{SD}$ ), respectively. Values in the other groups represent triplicates.

(0.25 mg, 11.1 $\pm 2.4 \% ; 0.5 \mathrm{mg}, 13.7 \pm 0.8 \% ; 1 \mathrm{mg}, 13.9 \pm 1.0 \%$; basal, $12.9 \pm 2.6 \% ; n=3, P=\mathrm{NS})$. The hCG block on ${ }^{131}$ I-thyroxine production was apparently overcome by increasing bTSH dose, and only a minor inhibiting effect of $700 \mu \mathrm{g}$ asialoagalacto-hCG was seen in animals treated with $100 \mathrm{mIU}$ bTSH each (bTSH alone, $31.6 \pm 1.84 \%, n=4$, vs. bTSH plus asialoagalacto-hCG, $27.1 \pm 2.1 \%, n=4, P=\mathrm{NS}$ ).

In addition, a marked increase in nuclear volumes of thyroid follicular cells was seen in transplants of animals receiving bTSH $(0.1 \mathrm{mIU})$, but not in animals that had received combined treatment with asialoagalacto-hCG and bTSH. The data are shown in Table I.

In these experiments, concentrations of holo-hCG immunoreactivity present in the serum of the mice $20 \mathrm{~min}$ after asialoagalacto-hCG injections were as follows: $4.6 \pm 2.9 \mu \mathrm{g} / \mathrm{ml}(x \pm \mathrm{SD}$, $n=3)$ in animals injected with $0.25 \mathrm{mg}, 11.0 \pm 4.9 \mu \mathrm{g} / \mathrm{ml}$ in animals injected with $0.5 \mathrm{mg}(n=3)$ and $25.5 \pm 11.6 \mu \mathrm{g} / \mathrm{ml}$ in animals injected with $1 \mathrm{mg}$ asialoagalacto-hCG $(n=6)$. As expected, in the groups of animals treated with saline and bTSH alone no hCG-immunoreactivity was found.

Studies of HLA-DR expression in the nude mouse. To study the effects of asialoagalacto-hCG on HLA-DR expression in human thyroid transplants single injections of bTSH and/or asialoagalacto-hCG were administered, in the absence and presence of $\gamma$-interferon which was continuously infused, for $3 \mathrm{~d}$. Table II summarizes the results of these experiments. The data show a dose-related inhibition by asialoagalacto-hCG of the bTSH effect on DR expression by thyrocytes in the presence of $\gamma$-interferon ( $\sim 75 \%$ DR-positive cells). The $\gamma$-interferon effect alone $(\sim 45 \%)$, however, was not significantly affected by the hCG variant. Asialoagalacto-hCG alone resulted in a percentage of $<3 \%$ DR-positive thyrocytes in the transplants, and so did bTSH alone and saline.

\section{Discussion}

In the present studies we describe and characterize a TSH receptor antagonist that was obtained by chemically modifying the hCG molecule and inhibits various responses of human thyroid to bTSH in vitro as well as in a nude mouse model under in vivo conditions. This particular variant of hCG, asia-
Table I. Inhibition of bTSH Effect on Hypertrophy of Follicular Cells in Human Thyroid Transplants by Asialoagalacto-hCG in the Nude Mouse

\begin{tabular}{lc}
\hline \multicolumn{1}{c}{ Substances } & Nuclear volume \\
\hline & $\mu m^{3}$ \\
bTSH $(0.1 \mathrm{mIU} /$ animal $)$ & $145 \pm 5.0^{\ddagger}$ \\
bTSH $(0.1 \mathrm{mIU} /$ animal $)+$ asialoagalacto-hCG & \\
$0.25 \mathrm{mg} /$ animal & $130 \pm 7.8^{* \neq}$ \\
$0.5 \mathrm{mg} /$ animal & $110 \pm 6.1^{\ddagger}$ \\
$1 \mathrm{mg} /$ animal & $95 \pm 5.8^{*}$ \\
Asialoagalacto-hCG & \\
$0.25 \mathrm{mg} /$ animal & $93 \pm 4.9^{*}$ \\
$0.5 \mathrm{mg} /$ animal & $92 \pm 6.5^{*}$ \\
$1 \mathrm{mg} /$ animal & $90 \pm 4.5^{*}$ \\
Saline & $92 \pm 6.3^{*}$
\end{tabular}

$x \pm \mathrm{SD}, n=3$.

* $P<0.01$ compared to bTSH.

${ }^{\ddagger} P<0.01$ compared to saline.

loagalacto-hCG, favorably combines the properties of a high affinity for human TSH receptor and a limited affinity for hepatic receptors that are responsible for the extremely rapid plasma clearance of asialo-hCG $(32,33)$.

The aspects of the physiology of asialoagalacto-hCG related to its interaction with the thyroid TSH receptor have apparently not been examined previously, except for some preliminary results published by our group (34). Only, some data on the interaction of this hCG variant with the ovarian and testis hCG receptor, mainly of rat origin, are available (35-38). From

Table II. Inhibition of bTSH Effect on $\gamma$-Interferon-induced HLA-DR Expression in Human Thyroid Transplants by Asialoagalacto-hCG in the Nude Mouse

\begin{tabular}{lc}
\hline \multicolumn{1}{c}{ Substances } & $\begin{array}{c}\text { Percentage of HLA-DR } \\
\text { positive thyroid } \\
\text { follicular cells }\end{array}$ \\
\hline$\gamma$-Interferon + bTSH & $75 \pm 3.0^{\ddagger}$ \\
$\gamma$-Interferon + bTSH + asialoagalacto-hCG & \\
$0.25 \mathrm{mg} /$ animal & $71 \pm 4.5^{\ddagger}$ \\
$0.5 \mathrm{mg} /$ animal & $60 \pm 3.5^{* \ddagger}$ \\
$1 \mathrm{mg} /$ animal & $46 \pm 2.5^{*}$ \\
$\gamma$-Interferon & $45 \pm 4.0^{*}$ \\
$\gamma$-Interferon + asialoagalacto-hCG & \\
$0.25 \mathrm{mg} /$ animal & $44 \pm 6.0^{*}$ \\
$0.5 \mathrm{mg} /$ animal & $46 \pm 3.5^{*}$ \\
$1 \mathrm{mg} /$ animal & $50 \pm 5.5^{*}$ \\
Asialoagalacto-hCG $(0.25,0.5,1 \mathrm{mg})$ & $<3^{* \ddagger}$ \\
bTSH & $<3^{* \ddagger}$ \\
Saline & $<3^{* \neq}$ \\
\hline
\end{tabular}

$\gamma$-Interferon (200 IU/d) was continuously supplied by infusion for 3 d, bTSH ( $0.1 \mathrm{mIU} / \mathrm{animal})$ and asialoagalacto-hCG were injected as single doses on $3 \mathrm{~d}$ (see text and Methods). Results represent the means \pm SD obtained in five animals per group.

${ }^{*} P<0.01$ compared to $\gamma$-interferon + bTSH.

${ }^{\ddagger} P<0.01$ compared to $\gamma$-interferon. 
a methodological point of view it is important to note that previously published procedures for preparing asialoagalactohCG by treating asialo-hCG with $\beta$-galactosidase from Aspergillus niger (15) were somewhat unsatisfactorily employed in our hands as their use resulted in considerable release of free $\beta$-subunit which is biologically inactive. This problem, however, could be overcome by introducing a slight modification of the protocol performing enzymatic digestion at $22^{\circ} \mathrm{C}$ instead of $37^{\circ} \mathrm{C}$.

As expected from previously published data $(9,13,39,40)$, removal of sialic acid from $h C G$ resulted in a sharp enhancement of its affinity for TSH receptor in human thyroid membranes. Removal of terminal galactose in addition to sialic acid brought only little further increase in affinity for TSH receptor, and so did nearly complete removal of carbohydrate by the HF method. With respect to its TSH antagonism, asialoagalactohCG proved at least as potent as asialo-hCG and slightly less potent than deglycosylated hCG as judged by the abilities of the substances to inhibit the stimulation of adenylate cyclase activity by bTSH in human thyroid membranes. In that respect, asialoagalacto-hCG exhibited a much higher potency than other relatively long-lived TSH receptor antagonists (alpha-BF, asialo-alpha-BF) we had described in a previous report (13). Another aim of the present study was to document an inhibitory effect of TSH receptor antagonists on bTSH-stimulated hormonal endpoint response, because this was apparently not included in previous studies. Indeed, we could show a dose dependent inhibition of bTSH stimulation of $T_{3}$ release in human thyroid slices by both asialo-hCG and asialoagalacto-hCG.

Binding studies to rat liver membranes were performed next because a close relation between plasma half lives of hCG forms and their affinities for hepatic receptors for asialoglycoproteins had been well established in a number of previous studies including our own work $(13,32,33)$. Thus, the desialylated form of hCG, asialo-hCG, binds with high affinity to, and is rapidly cleared by these receptors and as a result has a halflife in the range of minutes only, whereas hCG itself has little affinity for hepatic receptors and survives in the circulation for several hours $(41,42)$. As a consequence, asialo-hCG does not retain its in vitro gonadotropic activity in vivo $(32,37,43)$. For asialoagalacto-hCG, however, we found a 300 -fold lower affinity for asialo-hCG receptor in rat liver membranes when directly compared with asialo-hCG in the same assay. In that respect, deglycosylation did not lead to any further diminution of hepatic binding. These data underline the essential role of terminal galactose in the interaction of asialoglycoproteins with liver receptors that has previously been described by Ashwell and others (44).

By taking advantage of differences in carbohydrate requirements for interaction with thyroid TSH receptor and hepatic asialoglycoprotein receptors we succeeded in obtaining two variants of hCG, asialoagalacto-hCG, and deglycosylated hCG, that exhibited a limited affinity for liver receptors and at the same time retained a strong thyroid inhibitory potency. Experiments that would permit an exact analysis of their elimination kinetics or calculation of their plasma half-lives were not performed in the present studies. However, we did measure holohCG immunoreactivities present in the serum of the mice 20 min after injecting asialoagalacto-hCG. As expected, serum concentrations of holo-hCG immunoreactivity were related to the dose of asialoagalacto-hCG administered being at this time $\sim 25 \mu \mathrm{g} / \mathrm{ml}$ per mg of substance injected. This is in accord with earlier reports showing significantly prolonged plasma halflives of asialoagalacto-hCG and galactose oxidized hCG variants compared to asialo-hCG $(36,37)$.

For in vivo testing as a thyroid blocker, we deliberately selected asialoagalacto-hCG rather than deglycosylated hCG, which appeared at least as good a candidate, mainly for reasons that asialoagalacto-hCG obtained by enzymatic methods was a better defined substance available in higher yield, higher purity, and higher homogeneity than deglycosylated hCG, which had been prepared by a chemical method. The choice of a suitable animal model appeared to be difficult, because a substantial species-related variation in thyroid response to $h C G$ is well known. Thus, intact hCG from pregnancy sources is a stimulator of significant potency in the rodent thyroid in vitro and in vivo (45-48), whereas in the human thyroid it was reported to exhibit little, if any, thyrotropic activity (49-51). Moreover, desialylation and deglycosylation of hCG increase its agonistic activity measured by cAMP response in rat thyroid cells (FRTL-5) rather than transforming it into a pure antagonist like in the human thyroid (18).

For those reasons, we were particularly interested to study human thyroid and decided to use the nude mouse bearing human thyroid transplants. In this model, the in vivo effects of bTSH and other thyroid stimulators have been well characterized. Particularly, a functional activity and responsiveness of the human thyroid transplants to bTSH stimulation has been shown previously by histomorphological criteria, ${ }^{131}$ iodine scintigraphy and serum thyroid hormone measurements (28, $29,52,53)$. Thus, ${ }^{131}$ iodide administered to the mice, in addition to its uptake by the mouse thyroid, is avidly taken up by the transplants and incorporated into thyroid hormones that are newly synthesized and released into the circulation $(28,53)$. Reflecting transplant function, ${ }^{131} \mathrm{I}$-thyroxine accumulation measured in the serum $24 \mathrm{~h}$ after injecting radioactively labeled iodine was higher in animals bearing human thyroid transplants as compared to mice without transplant, and this difference was even more pronounced upon stimulation by bTSH. Treatment of transplant bearing animals with asialoagalactohCG before bTSH stimulation resulted in a significant, doserelated decrease of ${ }^{131} \mathrm{I}$-thyroxine serum concentrations as compared to those in the group of animals treated with bTSH alone. The magnitude of inhibition indicated that both transplant and mouse thyroid were affected. Thus, the TSH antagonistic activity of the hCG variant apparently prevailed over its weak mouse thyroid stimulatory potency under these conditions. The mode of inhibition appeared to be competitive, as it is in vitro (9), because the block of bTSH stimulation was abolished by increasing bTSH dose. Because ${ }^{131} \mathrm{I}$-thyroxine production was dependent on both the human thyroid transplanted and the mouse thyroid it was desirable to have in addition a measure of the function of the human thyroid transplants themselves. Therefore, we determined the nuclear volumes of thyroid follicular cells in frozen transplant sections. In this respect, bTSH induced cellular hypertrophy of human thyrocytes in the transplants could be prevented by treatment with asialoagalacto-hCG. The data add strong evidence that asialoagalacto-hCG was indeed able to block human TSH receptor in the nude mouse bearing human thyroid transplants.

Finally, in view of the putative key role of HLA class II antigen presentation on thyrocytes in propagating autoimmune thyroid disease (54-56), we were interested to find out if 
blockade of TSH receptor by asialoagalacto-hCG may also prevent TSH effect on $\gamma$-interferon induced DR expression on human thyroid transplant cells in the nude mouse model in vivo. Indeed, we could document a dose-dependent decline in the percentage of HLA-DR positive thyrocytes in transplants stimulated by bTSH and $\gamma$-interferon by treating the animals with asialoagalacto-hCG. As expected, there was no complete inhibition of DR expression, because DR expression in response to $\gamma$-interferon alone was not affected by asialoagalactohCG. This, however, would not necessarily preclude a theoretically possible use of TSH receptor antagonists to control antigen expression in Graves' disease, because reduced antigen expression should result in reduced numbers of $T$ helper cells being activated, and this, in turn, should reduce $\gamma$-interferon production as well as TSAb production initiating a beneficial cycle which would then repeat itself.

In conclusion, in the present studies we describe the preparation and characterization of a variant of $\mathrm{hCG}$, asialoagalacto$\mathrm{hCG}$, that antagonizes various effects of bTSH in human thyroid in vitro, and, more importantly, in an in vivo model, the nude mouse bearing human thyroid transplants. The data provide evidence that such a substance may successfully be used in vitro as well as in vivo to block both thyroid hormone production and HLA-DR expression brought about by TSH receptor activation. Hence, the concept of antagonizing actions of thyroid stimulators at the receptor level may warrant further exploration for a possible use in the management of Graves' disease and the present findings may help to eventually obtain a thyroid blocker for clinical application.

\section{Acknowledgments}

This work was supported by Grant Ho 1037/2-1 from the Deutsche Forschungsgemeinschaft, Bonn, Germany.

\section{References}

1. Smith, B. R., S. M. McLachlan, and J. Furmaniak. 1988. Autoantibodies to the thyrotropin receptor. Endocr. Rev. 9:106-121.

2. Bodolay, E., G. Szegedi, P. Suranyi, F. Juhasz, V. Stenszky, C. Balazs, and N. R. Farid. 1987. Expression of HLA-DR antigens by thyroid cells: the effect of Graves' IgG. Immunol. Lett. 15:77-81.

3. Todd, I., J. M. McNally, L. Hammond, and R. Pujoll-Borell, 1986. TSH enhances expression by thyrocytes of interferon-gamma induced HLA-D/DR and of microvillar antigen. In Frontiers in Thyroidology. G. Medeiros-Neto and E. Gaitan, editors. Plenum Publishing Corp., New York. 1551-1554.

4. Amir, S. M., K. Kubota, D. Tramontano, S. H. Ingbar, and H. T. Keutmann. 1987. The carbohydrate moiety of bovine thyrotropin is essential for full bioactivity but not for receptor recognition. Endocrinology. 120:345-352.

5. Joshi, L. R., and B. D. Weintraub. 1983. Naturally occuring forms of thyrotropin with low bioactivity and altered carbohydrate content act as competitive antagonists to more bioactive forms. Endocrinology. 113:2145-2154.

6. Morris III, J. C., N. S. Jiang, M. C. Charlesworth, D. J. McCormick, and R. J. Ryan. 1988. The effects of synthetic $\alpha$-subunit peptides on thyrotropin interaction with its receptor. Endocrinology. 123:456-462.

7. Freeman, S. L., J. C. Morris, D. J. McCormick and R. J. Ryan 1989. Inhibition of TSH and TSI stimulated cAMP generation by synthetic human TSH-beta peptides. 64th Meeting of the American Thyroid Association, San Francisco. T-52 (Abstr.)

8. Carayon, P., S. Amr, and B. Nisula. 1980. A competitive antagonist of thyrotropin: asialochoriogonadotropin. Biochem. Biophys. Res. Commun. 97:69-74.

9. Hoermann, R., S. M. Amir, and S. H. Ingbar. 1988. Evidence that partially desialylated variants of human chorionic gonadotropin (hCG) are the factors in crude hCG that inhibit the response to thyrotropin in human thyroid membranes. Endocrinology. 123:1535-1543.

10. Uchimura, H., S. Nagataki, K. Ito, S. M. Amir, and S. H. Ingbar. 1982. Inhibition of the thyroid adenylate cyclase response to thyroid-stimulating immunoglobulins $\mathrm{G}$ by crude and asialo-human chorionic gonadotropin. J. Clin. Endocrinol. \& Metab. 55:347-353.
11. Morris III, J. C., N. S. Jiang, I. D. Hay, M. C. Charlesworth, D. J. McCormick, and R. J. Ryan. 1988. The effects of synthetic $\alpha$-subunit peptides on thyroid stimulating immunoglobulin activity. J. Clin. Endocrinol. \& Metab. 67:707712.

12. van Hall, E. V., J. L. Vaitukaitis, G. T. Ross, J. H. Hickman, and G. G. Ashwell. 1971. Immunological and biological activities of $\mathrm{hCG}$ following progressive desialylation. Endocrinology. 88:456-464.

13. Hoermann, R., S. M. Amir, T. Nomura, and S. H. Ingbar. 1989. Design of a long-lived thyrotropin antagonist from derivatives of human chorionic gonadotropin. Endocrinology. 124:223-232.

14. Warren, L. 1959. The thiobarbituratic acid assay of sialic acids. J. Biol. Chem. 234:1971-1975.

15. Bahl, O. P. 1969. Human chorionic gonadotropin, nature of the carbohydrate units. J. Biol. Chem. 211:575-583.

16. Spiro, R. G. 1966. Analysis of sugars found in glycoproteins. Methods Enzymol. 3:7-8.

17. Keutmann, H. T., P. J. Mcllroy, E. R. Bergert, and R. J. Ryan. 1983. Chemically deglycosylated human chorionic gonadotropin subunits: characterization and biological properties. Biochemistry. 22:3067-3072.

18. Hoermann, R., H. T. Keutmann, and S. M. Amir. 1991. Carbohydrate modifications transform human chorionic gonadotropin into a potent stimulator of adenosine 3',5'-monophosphate and growth responses in FRTL-5 thyroid cells. Endocrinology. 128:1129-1135.

19. Mann, K., N. Schneider, and R. Hoermann. 1986. Thyrotropic activity of acidic isoelectric variants of human chorionic gonadotropin from trophoblastic tumors. Endocrinology. 118:1558-1566.

20. Kyhse-Andersen, J. 1984. A simple horizontal apparatus without buffer tank for electrophoretic transfer of proteins from polyacrylamide gels to nitrocellulose. J. Biochem. Biophys. Methods. 10:203-209.

21. Siddle, K., T. Gard, D. Thomas, M. P. Cranage, and R. R. A. Coombs. 1984. Red cell-labelled monoclonal antibodies for assay of human chorionic gonadotropin and luteinising hormone by reverse passive haemagglutination. $J$. Immunol. Methods. 73:169-176.

22. Mann, K., and K. Siddle. 1988. Evidence for free beta-subunit secretion in so called hCG-positive seminoma. Cancer (Phila.). 62:2378-2382.

23. Hoermann, R., G. Spoettl, R. Moncayo, and K. Mann. 1990. Evidence for the presence of human chorionic gonadotropin (hCG) and free $\beta$-subunit of hCG in the human pituitary. J. Clin. Endocrinol. \& Metab. 71:179-186.

24. Goldfine, I. K., S. M. Amir, A. W. Petersen, and S. H. Ingbar. 1974. Preparation of biologically active ${ }^{125} \mathrm{I}-\mathrm{TSH}$. Endocrinology. 95:1228-1233.

25. Powell-Jones, C. H., C. G. Thomas, and S. N. Nayfeh. 1980. Thyrotropin receptors in normal human thyroid. J. Biol. Chem. 255:4001-4010.

26. Orgiazzi, J., D. E. Williams, I. J. Chopra, and D. H. Soloman. 1976. Human thyroid adenylate cyclase stimulating activity in immunoglobulin $G$ of patients with Graves' disease. J. Clin. Endocrinol. \& Metab. 42:341-354.

27. Atkinson, S., and P. Kendall-Taylor. 1981. The stimulation of thyroid hormone secretion in vitro by thyroid stimulating antibodies. J. Clin. Endocrinol. \& Metab. 53:1263-1266.

28. Schumm-Draeger, P. M., K. H. Usadel, B. O. Boehm, F. D. Maul, H. J. C. Wenisch, R. Senekowitsch, C. R. Pickardt, and K. Schoeffling. 1987. Thyrotoxic effect of high iodine doses on xenotransplanted autoimmune thyroid tissue in athymic nude mice. Acta Endocrinol. Suppl. 281:118-121.

29. Usadel, K. H., J. Teuber, R. Paschke, M. Junker, and U. Schwedes. 1987. Transplantation of human endocrine tissues to nude mice: a suitable in vivo model for the study of pathomechanisms involved in autoimmune thyroid diseases. Acta Endocrinol. Suppl. 281:77-81.

30. Schumm-Draeger, P. M., B. O. Boehm, H. J. C. Wenisch, and K. Schoeffling. 1991. Effects of gamma-interferon and interleukin-2 on xenotransplanted human thyroid tissue. In Autoimmune Thyroiditis: Approaches towards its Etiological Differentiation. W. A. Scherbaum, U. Bogner, B. Weinheimer, and G. F Bottazzo, editors. Springer-Verlag, Inc., New York. 299-304.

31. Bradford, M. M. 1976. A rapid and sensitive method for the quantitation of microgram quantities of protein utilizing the principle of protein-dye binding. Anal. Biochem. 72:248-254.

32. Morell, A. G., G. Gregoriadis, K. Ito, I. H. Scheinberg, J. Hickman, and G. Ashwell. 1971. The role of sialic acid in determining the survival of glycoproteins in the circulation. J. Biol. Chem. 246:1461-1467.

33. van Hall, E. V., J. L. Vaitukaitis, G. T. Ross, J. W. Hickman, and G. Ashwell. 1971. Effects of progressive desialylation on the rate of disappearance of immunoreactive hCG from plasma in rats. Endocrinology. 89:11-15.

34. Hoermann, R., K. Rehbach, and K. Mann. 1990. Asialoagalacto-choriongonadotropin, an antagonist of the actions of Graves' immunoglobulins with a limited affinity for hepatic receptors. Horm. Metab. Res. 22:196-197.

35. Kalyan, N. K., H. A. Lippes, and O. P. Bahl. 1982. Role of carbohydrate in human chorionic gonadotropin: effects of periodate oxidation and reduction on its in vitro and in vivo biological properties. J. Biol. Chem. 257:12624-12631.

36. Madnick, H. M., N. K. Kalyan, H. L. Segal, and O. P. Bahl. 1981. Effect of modification of galactose residues on the biological properties of asialo human choriogonadotropin. Arch. Biochem. Biophys. 212:432-442. 
37. Tsuruhara, T., M. L. Dufau, J. Hickman, and K. J. Catt. 1972. Biological properties of hCG after removal of terminal sialic acid and galactose residues. Endocrinology. 91:296-301.

38. Brand, E. C., and J. Odink. 1980. The effect of galactose oxidase treatment on the hepatic binding and biological activity of desialylated human chorionic gonadotrophin. Acta Endocrinol. 93:234-242.

39. Amir, S. M., R. Sullivan, and S. H. Ingbar. 1978. The effect of desialylation on the in vitro interaction of human chorionic gonadotropin with human thyroid plasma membranes. Endocrinology. 109:1203-1211.

40. Amr, S., Y. Shimohigashi, P. Carayon, H. C. Chen, and B. Nisula. 1984. Role of the carbohydrate moiety of human choriogonadotropin in its thyrotropic activity. Arch. Biochem. Biophys. 229:170-176.

41. Wehmann, R. E., and B. C. Nisula. 1981. Metabolic and renal clearance rates of purified human chorionic gonadotropin. J. Clin. Invest. 68:184-194.

42. Rosa, C., S. Amr, S. Birken, R. Wehmann, and B. Nisula. 1984. Effect of desialylation of human chorionic gonadotropin on its metabolic clearance rate in humans. J. Clin. Endocrinol. \& Metab. 59:1215-1219.

43. van Hall, E. F., J. L. Vaitukaitis, G. T. Ross, J. W. Hickman, and G. Ashwell. 1971. Immunological and biological activity of hCG following progressive desialylation. Endocrinology. 88:456-464.

44. Ashwell, G., and J. Harford. 1982. Carbohydrate-specific receptors of the liver. Annu. Rev. Biochem. 51:531-554.

45. Amir, S. M., K. Endo, R. Osathanondt, and S. H. Ingbar. 1985. Divergent responses by human and mouse thyroids to human chorionic gonadotropin in vitro. Mol. Cell. Endocrinol. 39:31-37.

46. Davies, T. F., and M. Platzer. 1986. hCG-induced TSH receptor activation and growth acceleration in FRTL-5 cells. Endocrinology. 118:2149-2151.

47. Nisula, B. C., and J. M. Ketelslegers. 1974. Thyroid-stimulating activity and chorionic gonadotropin. J. Clin. Invest. 54:494-499.

48. Kenimer, J. G., J. M. Hershman, and H. P. Higgins. 1975. The thyrotropin in hydatiform mole is human chorionic gonadotropin. J. Clin. Endocrinol. \& Metab. 40:482-489.
49. Carayon, P., G. Lefort, and B. C. Nisula. 1980. Interaction of human chorionic gonadotropin and human luteinizing hormone with human thyroid membranes. Endocrinology. 106:1907-1916.

50. Nisula, B. C., G. S. Taliadouros, and P. Carayon. 1980. Primary and secondary biologic activities intrinsic to the human chorionic gonadotropin molecule. In Chorionic Gonadotropin. S. Segal, editor. Plenum Publishing Corp., New York. 17-35.

51. Amir, S. M. 1986. Human chorionic gonadotropin: a negligible human thyroid stimulator. In Werner's The Thyroid. 5th ed. S. H. Ingbar and L. E. Braverman, editors. J. B. Lippincott Co., Philadelphia. 1088-1097.

52. Schumm, P. M., H. J. C. Wenisch, U. Schwedes, F. D. Maul, and K. H. Usadel. 1984. A bioassay to determine thyroid-stimulating immunoglobulins (TSI) by means of heterotransplantation of human thyroid tissue to athymic nude mice. In Autoimmunity in Thyroid Disorders. H. Schatz and D. Doniach, editors. Georg Thieme Verlag, New York. 52-61.

53. Usadel, K. H., P. M. Schumm, H. J. C. Wenisch, F. D. Maul, and U. Schwedes. 1984. Transplantation of thyroid tissue to nude mice: a method for demonstrating extrinsic stimulators, and a new bioassay for thyroid stimulating antibodies (TSI). In Current Topics in Thyroid Autoimmunity. D. Doniach, $\mathrm{H}$ Schleusener, and B. Weintraub, editors. Georg Thieme Verlag, New York. 187-198.

54. Bottazzo, G. F., R. Pujol-Borell, T. Hanafusa, and M. Feldman. 1983. Role of aberrant HLA-DR expression and antigen presentation in induction of endocrine autoimmunity. Lancet. ii:1115-1119.

55. Volpe, R., A. Karlson, R. Jansson, and P. A. Dahlberg. 1987. Thyrostatic drugs act through modulation of thyroid cell activity to induce remission of Graves' disease. In Advances in Thyroidology. B. E. Wenzel and G. F. Bottazzo, editors. Acta Endocrinol. Suppl. 281:305-311.

56. Davies, T. F., and L. A. Piccinini. 1987. Intrathyroidal MHC class II antigen expression and thyroid autoimmunity. Endocrinol. Metab. Clin. North Am. 16:247-268. 